\title{
EFFECTS OF CONTROLLED FIRE ON HYDROLOGY AND EROSION UNDER SIMULATED RAINFALL
}

\author{
S.D. KEESSTRA ${ }^{1}$, J. MAROULIS ${ }^{1}$, E. ARGAMAN ${ }^{3}$, A. VOOGT ${ }^{1}$, \\ L. WITTENBERG ${ }^{2}$
}

${ }^{1}$ Soil Physics and Land Management Group, Wageningen University, Wageningen, Netherlands.
${ }^{2}$ Department of Geography and Environmental Studies, University of Haifa, Haifa, Israel.
${ }^{3}$ Soil Erosion Research Station, Ministry of Agriculture and Rural Development, Ruppin, Israel.

\begin{abstract}
Mediterranean forests are frequently subject to wildfires, inducing risks of high runoff and loss of nutrient-rich topsoil. The mechanisms influencing these post-fire effects are spatially variable due to differences in vegetation density, litter composition, soil texture and structure, and fire intensity, and therefore difficult to separate. The characteristics of the soil surface in the immediate post-fire period are of critical importance to the hydrological response and erosion susceptibility of the burnt hillslope and catchment. In laboratory experiments, uniform soil, controlled temperature and rain regimes were used to create a controlled environment to isolate the impact of certain influencing parameters. In this study, for a Rendzina soil, we investigated the post-fire impacts of laboratory fire and two successive rainfall (rotating disktype) simulation experiments to evaluate short-term effects of fire on soil hydrological and erodibility parameters by examining (i) soil water repellency (WR) levels and distribution, (ii) surface cover features, and (iii) infiltration, runoff and erosion responses to simulated rain on control (bare and pineneedle covered) and burnt (with and without ash cover) samples. Fire-induced surface WR tested in the laboratory by grid-wise Water Drop Penetration Time tests (WDPT), revealed moderate WR, which decreased for all treatments after rainfall. The response to rain $\left(33 \mathrm{~mm} \mathrm{~h}^{-1}\right)$ differed for the two simulation runs. The rates of drainage and runoff of the burnt samples in the first run varied between the values of cover (low runoff, high infiltration) and bare (high runoff, low infiltration). Drainage in the ash-covered samples was twice as high as ashremoved samples. In the second run, both samples showed a similar response compared to bare conditions. These laboratory observations suggest that WR and protection by ash are factors to consider in assessing the erosion susceptibility of a burnt forest soil. Furthermore, possible management implications based upon this research are that: 1) ash can have several important roles immediately after a forest fire by protecting the forest soil from rain splash erosion, and with its high water holding capacity, absorbs rainfall, thereby reducing runoff; and 2) ash has no negative influence upon soil infiltration demonstrating the important
\end{abstract}


benefits of ensuring the longer term maintenance of post-fire ash within the burnt landscape. Finally, management actions including mulching further enhance soil stability and minimize soil erosion.

\section{Efectos del fuego controlado sobre la hidrología y la erosión bajo lluvia si- mulada}

RESUMEN. Los bosques mediterráneos están frecuentemente sujetos a incendios, incrementando el riesgo de elevada escorrentía y pérdida de horizontes superiores del suelo ricos en nutrientes. Los mecanismos que influyen en estos efectos postincendio son espacialmente variables debido a diferencias en la densidad de la vegetación, composición del mantillo, textura y estructura del suelo, e intensidad del fuego, y por ello difíciles de separar. Las características del suelo y la superficie en el periodo inmediatamente posterior al incendio son de importancia crítica para la respuesta hidrológica y la susceptibilidad a la erosión de la ladera y la cuenca quemadas. En experimentos de laboratorio se utilizaron un suelo uniforme y situaciones controladas de temperatura y precipitación con el fin de aislar el impacto de algunos parámetros. En este estudio, para un suelo de Rendsina, investigamos los efectos post-incendio de un fuego de laboratorio y dos experimentos sucesivos de lluvia simulada para evaluar las consecuencias a corto plazo de un incendio sobre los parámetros hidrológicos y la erodibilidad del suelo, examinando (i) los niveles de repelencia al agua y su distribución, (ii) los rasgos de la cubierta superficial, y (iii) las respuestas de la infiltración, la escorrentía y la erosión frente a la lluvia simulada en una situación no perturbada (con suelo desnudo y cubierto de acículas) y quemada (con y sin cenizas). La repelencia al fuego, testada en laboratorio mediante pruebas de penetración de gotas de lluvia, reveló una repelencia moderada, que disminuyó para todos los tratamientos después de la lluvia. La respuesta frente a la lluvia $\left(33 \mathrm{~mm} \mathrm{~h}^{-1}\right)$ fue diferente para las dos series de simulaciones. Las tasas de drenaje y escorrentía en los casos quemados produjeron, en la primera prueba de simulación, valores situados entre la simulación en suelo cubierto (baja escorrentía, alta infiltración) y suelo desnudo (alta escorrentía, baja infiltración). El drenaje en los casos cubiertos de ceniza fue dos veces mayor que en los casos sin ceniza. En la segunda simulación, ambos ejemplos mostraron una respuesta similar comparada con las condiciones de suelo desnudo. Estas observaciones de laboratorio sugieren que la repelencia y la protección por las cenizas son factores para valorar la susceptibilidad a la erosión de suelos forestales quemados. Además, a partir de esta investigación pueden deducirse implicaciones para la gestión: 1) las cenizas pueden tener varias funciones importantes inmediatamente después de un incendio forestal al proteger el suelo del impacto de las gotas de lluvia, a la vez que su elevada capacidad de absorción de agua reduce la escorrentía; y 2) las cenizas no tienen una influencia negativa sobre la infiltración del suelo, demostrando los importantes beneficios de asegurar su presencia a largo plazo en el paisaje quemado. Finalmente, acciones tales como la incorporación de una capa de materia orgánica (mulching) incrementan la estabilidad del suelo y minimizan la erosión. 
Key words: wildfires, water repellency, ash, post-fire management, Mediterranean soils.

Palabras clave: incendios, repelencia al agua, cenizas, gestión post-incendio, suelos mediterráneos.

*Corresponding author: Soil Physics and Land Management Group, Wageningen University, Wageningen, Netherlands. E-mail: saskia.keesstra@wur.nl

\section{Introduction}

Forests in the Mediterranean basin are frequently subject to severe wildfires. Commonly, fire disturbance provokes significant impacts on soil properties and vegetation dynamics, as burnt steep slopes, which lack protective vegetative cover, are more susceptible to soil erosion and greater land degradation risks (Inbar et al., 1997, 1998; Pausas and Vallejo, 1999; Shakesby, 2011). In addition to the loss of the protective surface cover, fire alters physical and chemical properties of the soil; soil responses to fire are often site-specific and largely dependent on the size, intensity, and severity of the fire, and on the condition of the cover and density of vegetation at the time of burning (Keeley, 2009; Moody et al., 2013). Physical impacts of fire on soil include a breakdown in aggregated soil structure (Mataix-Solera et al., 2011), reduced moisture retention and capacity, production of a fire-induced ash layer (Bodi et al., 2013) and the development of water repellency (WR) in soils (DeBano, 2000), all of which affect soil hydrology and increase erosion susceptibility. Numerous wildfire related studies have documented the causes, effects and extent of fire-induced soil erosion at various scales, ranging from plot to catchment scales (e.g. Certini, 2005; Stoof et al., 2010; Moody et al., 2013), revealing a general trend of increased soil loss post-wildfires.

\subsection{Soil water repellency $(W R)$}

Soil WR is a natural trait, frequently evident in unburnt coarse-textured soils. Five key mechanisms are considered significant in generating WR in soils: a) fungal and microbial activity, b) growth of particular vegetation species, c) organic matter content, d) heating of the soils by wildfires and e) soil characteristics (Malkinson and Wittenberg, 2011). Natural WR is commonly related to the coating of soil particles with hydrophobic compounds leached from organic substances. Fire-induced WR, however, involves the volatilizing of hydrophobic organic compounds in the litter and topsoil; some of these compounds move through the soil and condense onto cooler soil grains, producing a hydrophobic repellent layer (Doerr et al., 2000). Under field conditions, WR, which is point-measured, markedly varies according to fire temperature (DeBano, 2000), soil grain size distribution (Mataix-Solera and Doerr, 2004), organic matter content and clay mineralogy (Mataix-Solera et al., 2008), soil moisture and vegetation type (Arcenegui et al., 2007; Doerr and Shakesby, 2009). Nonetheless, despite these related studies, 
relatively little is known about the explicit factors controlling the formation and intensity of post-fire soil WR (Doerr and Shakesby, 2009). In fact, one cannot relate elevated WR levels solely to the effects of fire (Stoof et al., 2010), as it is likely to vary greatly between vegetation and soil types (Shakesby, 2011). For example, Rendzina, a common soil in the Mediterranean area of Israel shows very low susceptibility to WR, both when burnt or unburnt (Mataix-Solera et al., 2008). Given the complex relations between field condition, fire characteristics and the development of WR, fire-induced WR typically appears in the soil as an episodic patchy layer of variable thickness (Mataix-Solera and Doerr, 2004; Doerr and Shakesby, 2009).

WR is also a key factor influencing post-fire hydrological and geomorphological processes, affecting soil infiltration capacity, overland flow generation, runoff and sediment yields (Wittenberg and Malkinson, 2009). However, although the effects of soil WR on runoff and erosion have been clearly demonstrated at the point-to-plot scale, it has been difficult to reveal its importance at much larger spatial scales (Shakesby et al., 2000; Blake et al., 2009).

\subsection{Post-wildfire impacts on hydrological processes}

Wildfires might have a significant, yet sometimes contrasting, influence on erosional dynamics. In addition to repellency-derived increased yields of runoff and erosion (Robichaud and Hungerford, 2000; Wittenberg et al., 2011), augmented soil loss rates are also associated with the remaining ash layer (Cerdà and Doerr, 2008; Larsen et al., 2009; Bodí et al., 2013). Ash might alter the soil hydrological properties, increasing water retention and reducing sediment transport (Cerdà and Doerr, 2008), but ash can also clog soil pores, seal the soil surface and increase surface erosion (Onda et al., 2008). Moreover, this protective layer reduces the direct impact of raindrop energy on the soil surface, thereby hampering sediment entrainment and surface crust-formation. However, the first rainstorms following a fire, ash layers are partly washed away while some can penetrate into the soil matrix (Larsen et al., 2009). The properties of the ash layer, including ash thickness, the degree of fully or partly combusted ash, and the extent of the homogenous spread of ash, can all determine the duration of soil surface protection (Bodí et al., 2012; Woods and Balfour, 2010).

Given the complex dynamics, a better understanding of the specific spatio-temporal mechanisms occurring in the immediate post-fire period is required to implement proper management practices to mitigate soil erosion hazards in burnt sites. Research on post-fire management actions reveals that logging and salvage harvesting (Thomas et al., 2000; Fernández et al., 2007; Smith et al., 2011) have a negative effect on erosion potential; while mulching (Prats et al., 2012; Robichaud et al., 2013) creates surface protection thereby reducing the soil erosion potential. However, actual erosion that will occur is a product of different processes. The most significant factors, other than the climatic and landscape setting of an area, are the effectiveness of the soil protective measures deployed, in combination with the actual soil physical and hydraulic properties and rainfall regime in the area. 
The approach deployed in this study mimics the different management techniques, but at the plot scale, as the controlled laboratory experiment of burning and two consecutive rainfall simulations will help evaluate the short-term effects of wildfires on the hydrological and erodibility parameters of forest soils. The soil consisted of a Rendzina soil taken from a forest in the north of Israel. We studied the dynamics of runoff and infiltration as a result of two successive simulated storms, with and without ash protection (which simulates management approaches). Furthermore, the erodibility of soil patches is determined when they are subject to high fire temperatures and typical summer-intensity rain, in relation to the extent of WR and ash impacts.

Rainfall simulations were performed to evaluate: (1) the effect of fire on the formation and persistence of soil WR when exposed to two successive rainfall simulations; (2) assess the dynamics of runoff and infiltration in two consecutive post-fire storms; (3) determine the importance of ash in protecting the soil against erosion; and then, (4) investigate the implications of post-fire soil physical and subsequent hydrological changes on post-fire management options.

\section{Methodology}

\subsection{Properties of leaf litter and soil}

Leaf litter of Pinus halepensis L., a common tree in the Mediterranean region, was collected in a forest patch with homogenous litter depth and tree distribution during dry days in the winter period of 2009. Unsorted soil was obtained from a forest site near the burnt Biriya forest (described previously in Wittenberg et al., 2011). The sampled soil is a Rendzina which is a soil commonly present in Israel. This soil contains large quantities of carbonates $\left(\mathrm{pH}=7.5 ; \mathrm{EC}=0.65 \mathrm{dS} \mathrm{m} \mathrm{m}^{-1}\right)$, high levels of clay $(25 \%$ sand, $30 \%$ silt, $45 \%$ clay) and low amounts of organic matter (1.02\%) (Soil Survey Staff, 1975). The unsorted and disturbed soil was dried at $60^{\circ} \mathrm{C}$ for $24 \mathrm{~h}$ and sieved into two aggregate size groups (0-4 $\mathrm{mm}$ and $0-15 \mathrm{~mm}$ ) to examine any differences that may be related to texture. Bulk density of the soil is $1.08 \mathrm{~g} \mathrm{ml}^{-1}$ with porosity at $49 \%$ for the $0-15 \mathrm{~mm}$ aggregate class and $56 \%$ for the $0-4 \mathrm{~mm}$ aggregates. After considerable drying, $\sim 1 \mathrm{~kg}$ of litter was placed on each soil sample.

\subsection{Burning Treatments}

Soil boxes $(48 \times 28 \times 5 \mathrm{~cm})$ with drainage perforations were prepared for the same initial conditions used in the rainfall simulation; i.e., uniform smooth surface and depth of soil profile. A single layer of dry gravel was laid out on the bottom of the box with a piece of permeable geotextile cloth on top (Fig. 1) to which approx. $7 \mathrm{~kg}$ of Rendzina soil was added. For each of the two aggregate size classes, 5 boxes were prepared which were further subdivided into unburnt (reference) and burnt treatments (Table 1). 


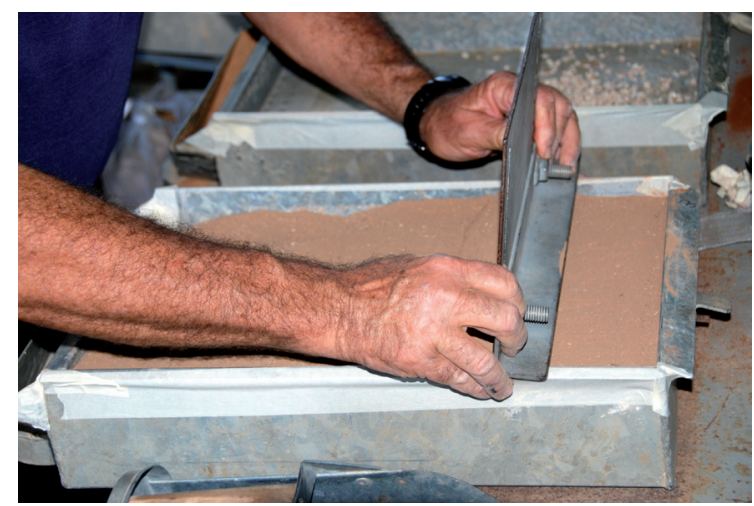

Figure 1. Preparation of treatment box with gauze, gravel, geotextile and soil.

Table 1. Overview of the 8 treatments for each burning regime and rainfall simulation with each treatment using two aggregate size classes: $0-4$ and 0-15 $\mathrm{mm}$.

\begin{tabular}{|l|l|l|}
\hline \multicolumn{1}{|c|}{ Treatments } & \multicolumn{1}{|c|}{ Bare (B) } & \multicolumn{1}{c|}{ Covered (C) } \\
\hline $\begin{array}{l}\text { Unburnt } \\
\text { (reference) }\end{array}$ & UB. Unburnt (bare soil) & $\begin{array}{l}\text { UC. Unburnt soil (with } \\
\text { pine needles })\end{array}$ \\
\hline *Burnt & $\begin{array}{l}\text { BB. *Burnt soil (with ash removed) } \\
\left(300^{\circ} \text { C for } 15 \text { min after addition of }\right. \\
\text { pine needles })\end{array}$ & $\begin{array}{l}\text { BC. *Burnt soil (with ash } \\
\text { maintained on surface) } \\
\left(300^{\circ} \text { C for 15 min after }\right. \\
\text { addition of pine needles) }\end{array}$ \\
\hline
\end{tabular}

The burning experiments were undertaken under controlled laboratory conditions, as field conditions precluded in situ rainfall simulation. Furthermore, transportation of blocks of burnt soil from the field to the laboratory would have disturbed the soil layers irreversibly. Litter was ignited and the time taken for all cover material to have combusted was measured (Fig. 2). Burn temperatures of $250-300^{\circ} \mathrm{C}$ were recorded using a thermocouple at temperatures that Doerr and Shakesby (2009) stated would intensify soil hydrophobicity. Depending on soil moisture and fire duration, temperatures $>280^{\circ} \mathrm{C}$ would further enhance the decomposition of the hydrophobic components.
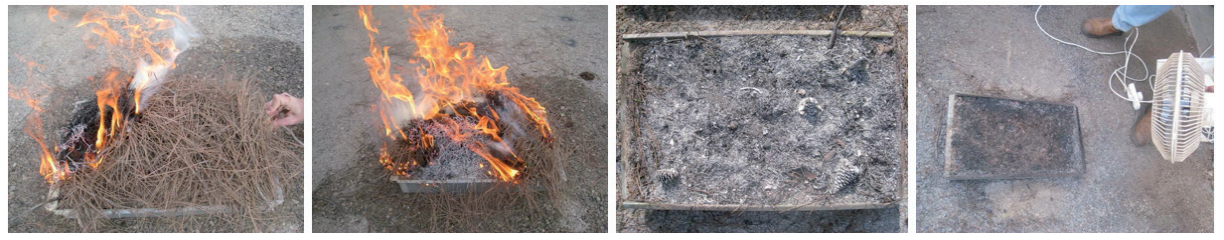

Figure 2. Steps involved in preparing the burnt soil box plots (fire simulation) in preparation for the rainfall simulator. 
After the burn, the surface of the burnt soil box samples with uncovered soil was subdivided by means of a removable $5 \times 5 \mathrm{~cm}$ grid (Fig. 3), with WR within each cell assessed by means of a Water Drop Penetration Time (WDPT) test. This test provides a measure of WR from a scale of wettable (hydrophilic) through to severe (Table 2). For instance, Class 1 represents a wettable soil (hydrophilic), but the higher the value, the more cells exist with some level of WR. No WDPT test was performed for treatment 4BC (0-4 mm aggregates: burnt+ash) before the rainfall simulation, to minimize disturbing the ash layer.

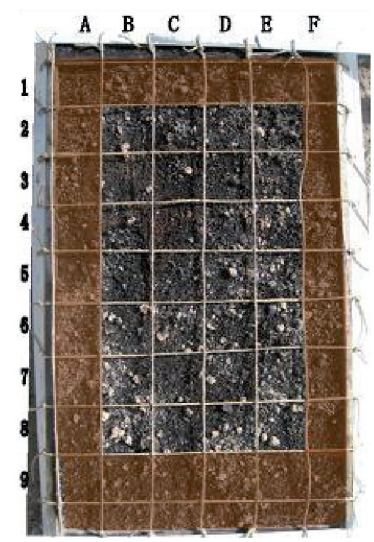

Figure 3. Grid for WDPT test; shaded area is not measured.

Table 2. Classification for Water Drop Penetration Time (WPDT) test (adjusted from Tessler et al., 2008).

\begin{tabular}{|c|c|c|}
\hline CLASS NO. & MAGNITUDE OF WATER REPELLENCY & INTERVAL (s) \\
\hline 1 & Wettable (hydrophilic) & $\leq 5$ \\
\hline 2 & Slight & $6-10$ \\
\hline 3 & \multirow{2}{*}{ Moderate } & $11-30$ \\
\hline 4 & & $31-60$ \\
\hline 5 & \multirow{2}{*}{ Strong } & $61-180$ \\
\hline 6 & & $181-300$ \\
\hline 7 & \multirow{2}{*}{ Severe } & $301-600$ \\
\hline 8 & & $>600$ \\
\hline
\end{tabular}

\subsection{Rainfall simulation}

Rainfall simulation took place over several hours with the five samples mounted on a five seat revolving platform positioned at a slope of 5\% (Fig. 4). The trays were filled with 8 to $10 \mathrm{~cm}$ disturbed, dried and sieved soil. The soil box samples were subjected to a constant rainfall intensity of $33 \mathrm{~mm} \mathrm{~h}^{-1}$, provided by a rotating-disk 
nozzle-type rainfall simulator housed at the Soil Erosion Research Station (SERS), Ruppin, Israel. For the simulation distilled water was used $(\mathrm{EC}=0)$. The rainfall simulation process was replicated twice, with an intervening drying period used to partly mimic the flashy Mediterranean rainy season. Between the simulations the trays are dried in a stove at a temperature of $40^{\circ} \mathrm{C}$, to avoid rapid shrinking of the (clayey) soil. The shallow soil profile was completely dry at the start of the second rainfall run. The first rainfall simulation experiment had a duration of 4 hours, the second run was stopped after 2 hours. Following each wetting phase, drainage and runoff were collected at intervals of $7 \mathrm{~min}$ for runoff and every $4 \mathrm{~min}$ for drainage, respectively, from which EC and sediment concentrations were measured. Steady EC values were used to check for constant flow and drainage. Each simulation was maintained until a steady infiltration rate was achieved.

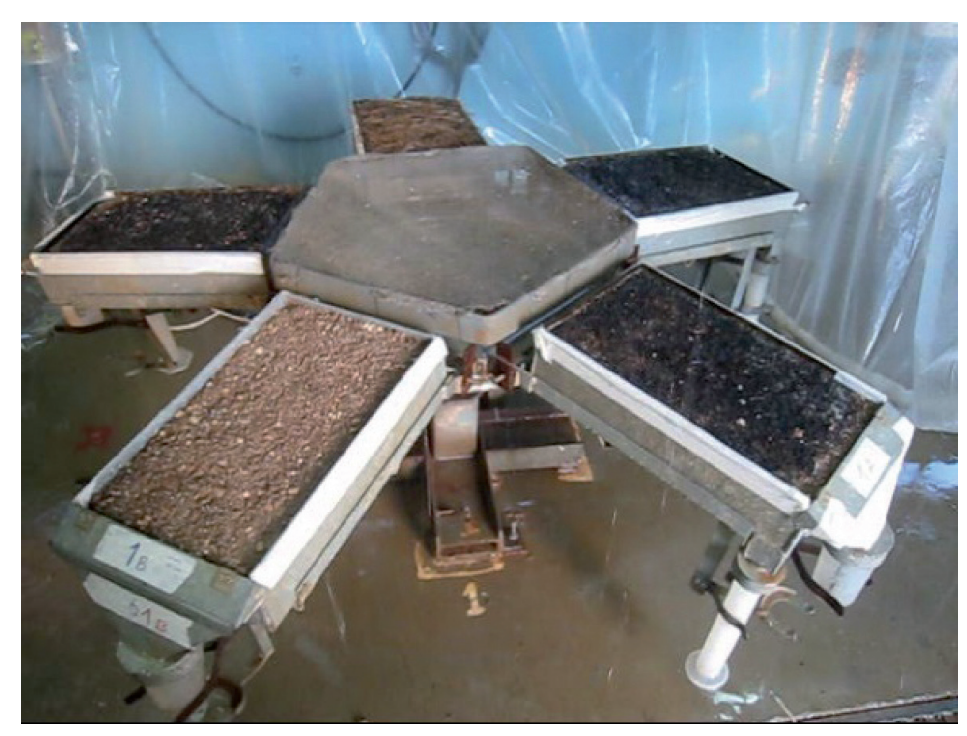

Figure 4 . The 5 tray platform rainfall simulator (Photo: Eli Argaman, 2010).

\section{Results}

\subsection{Effect of burning: water repellency (WR)}

Water repellency was tested twice (WR1, WR2; Table 3): before and after the first and second rainfall simulation. Thus, the effects of burning and the first rainstorm simulation of $2 \mathrm{~h}$ with a constant rain intensity of $33 \mathrm{~mm} \mathrm{~h}^{-1}$ were examined by analyzing both the qualitative (WR level and relation with surface characteristics) and quantitative (amount and spatial distribution of cells displaying WR) differences. 
Table 3. Frequency of WR levels for 2 WDPT tests (before and after 2 rainfall simulation runs) for 2 aggregate sizes (4 and $15 \mathrm{~mm}$ ) and 2 treatments ( 2 with and 2 without ash).

\begin{tabular}{|c|c|c|c|c|c|c|c|c|c|}
\hline & TREATMENT & \multicolumn{2}{|c|}{ 4-ash (4BB) } & \multicolumn{2}{|c|}{ 15-ash (15BB) } & \multicolumn{2}{|c|}{ 4+ash (4BC) } & \multicolumn{2}{|c|}{ 15+ash (15BC) } \\
\hline WR test* $^{* *}$ & $\mathbf{1}$ & $\mathbf{2}$ & $\mathbf{1}$ & $\mathbf{2}$ & $\mathbf{1}$ & $\mathbf{2}$ & $\mathbf{1}$ & $\mathbf{2}$ \\
\hline 1 & 117 & 96 & 102 & 108 & n.a. & 106 & 86 & 54 \\
\hline 2 & 3 & 11 & 10 & 13 & & 12 & 19 & 1 \\
\hline 3 & 3 & 2 & 8 & 6 & & 2 & 12 & 0 \\
\hline 4 & 0 & 1 & 3 & 0 & & 0 & 3 & 0 \\
\hline 5 & 0 & 1 & 2 & 0 & & 0 & 0 & 0 \\
\hline 6 & 0 & 2 & 1 & 1 & & 0 & 0 & 0 \\
\hline 7 & 0 & 0 & 0 & 0 & & 0 & 0 & 0 \\
\hline 8 & 0 & 0 & 2 & 0 & & 0 & 1 & 0 \\
\hline Average & $\mathbf{1 . 0 7}$ & $\mathbf{1 . 2 8}$ & $\mathbf{1 . 4 8}$ & $\mathbf{1 . 2 3}$ & - & $\mathbf{1 . 1 3}$ & $\mathbf{1 . 4 9}$ & $\mathbf{1 . 0 2}$ \\
\hline
\end{tabular}

$*$ Treatment number indicates maximum aggregate size; $* * 1=$ hydrophilic $(<5 s), 2=\operatorname{sight}(6-10 s)$, $3-4=$ moderate $(11-60 s) ; 5-6=$ strong $(61-300 s)$ and $7-8=$ severe $(>300 s)$.

Integration of the WR qualitative and quantitative data was achieved by calculating an average level of WR for the whole sample surface, which is defined by the WR levels present and the number of WR determined grid cells as the weighting factor. Class 1 represents a wettable soil (hydrophilic); the higher the WR value, the more cells exist with that level of WR (Table 3). Accordingly, the average WR level for the coarsest soil aggregate $(0-15 \mathrm{~mm})$ samples, 15-ash (15BB) and 15+ash (15BC), decrease from 1.48 to 1.23 and 1.49 to 1.02 , respectively. Where the presence of WR was largest on both treatments after the first rainfall simulation, the surface of both trays were largely hydrophilic after the second rainstorm. For 4-ash (4BB), this is the reverse, as the average increases from 1.07 to 1.28 (Fig. 5 and Table 3). However, this variation in WR is insufficient to cause significant concern as the post-burn soil is still rated wettable to slightly wettable (Table 2).

The results of WR2 of this treatment, however, show more cells with WR than in the finer $0-4 \mathrm{~mm}$ aggregate class of 4+ash (4BC), even after two rainfall simulations (Table 3). The treatment with the highest WR is 15-ash (15BB) in WR1, which has some grid cells with WR classified as strong/severe; but the WR2 tests on all other treatments revealed moderate to strong WR, with the majority of cells displaying slight or no WR (Table 3).

Several days after the fire, the burnt surfaces showed signs of hydrophobicity. Despite WR being relatively low (Class 2-3), there was a clear difference between the burnt and unburnt samples, with the unburnt soil surfaces being completely hydrophilic. The hydrophobicity of the surface of the burnt samples decreased after the first and final rain simulation, although at different rates. The treatments where ash remained on the surface, showed hydrophobicity in almost no cases, while the BB treatments retained higher WR levels. 


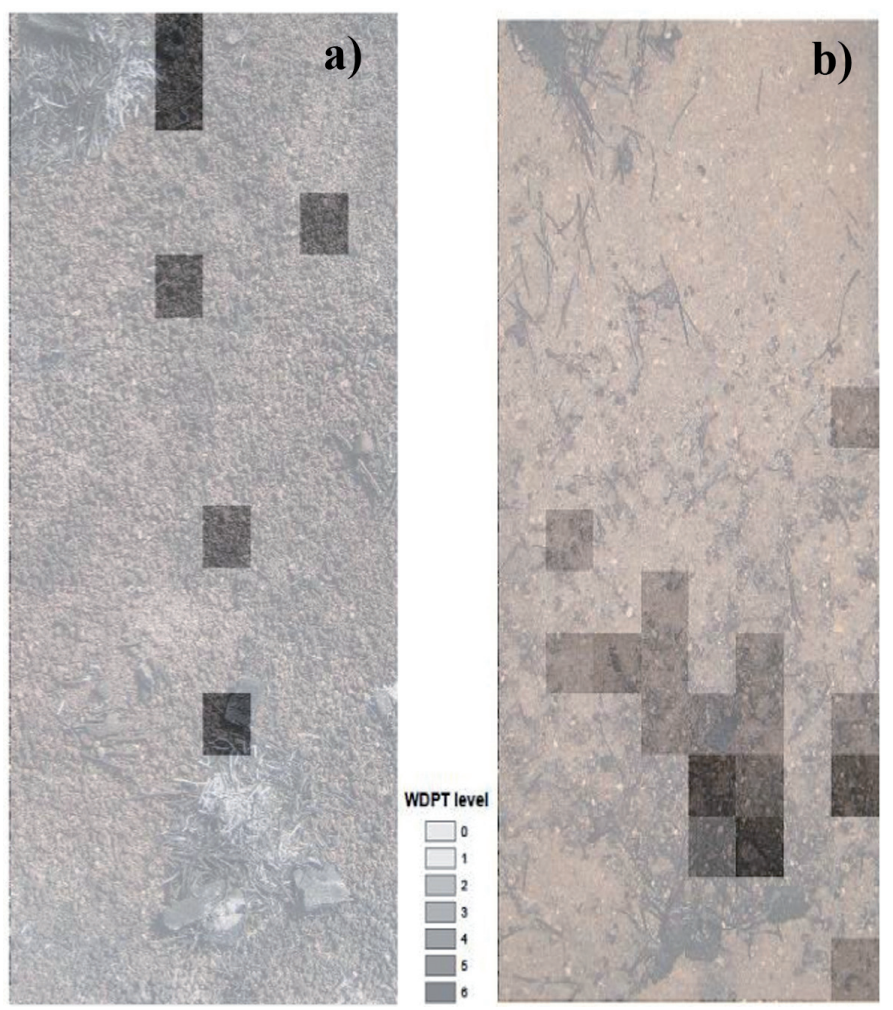

Figure 5. Schematic view of surface 4BB and position of WR cells during (a) WDPT1, and (b) WDPT2.

The position of surface areas with WR was not identical for all treatments (Fig. 5). The result of the first WDPT test on 4BB (Table 3) showed WR primarily along the centerline, where fire temperatures were expected to have been at their highest (Fig. 5a). In the second test, the hydrophobic area is mainly near the bottom of the soil box, which could imply transport of particles (water-repellent aggregates or organic litter components) down slope (Fig. 5b).

\subsection{Effect of burning: ash}

The litter amount used for the burning produced a thin layer of ash; with some areas black, while others white/grey indicating a wide range of temperatures in the fire. From relatively low temperatures (around $300^{\circ} \mathrm{C}$ ) creating black ash to high temperatures creating white ash (approximately $500^{\circ} \mathrm{C}$ ) (Úbeda et al., 2009). Because of the low fuel availability the ash layer was thin, up to several $\mathrm{mm}$ in thickness. In some instances the needle cover was only partially combusted, leaving charred needles on top in the soil (Fig. 2).

\subsection{Infiltration/drainage characteristics}

The two rainfall simulations (Runs 1 (R1) and 2 (R2)) for all treatments revealed similar initiation times for infiltration (Fig. 6a) but at different volumes of rainfall before drainage 
commenced. For Run 1 (Fig. 6a-R1), drainage was initiated after $20 \mathrm{~mm}$ of cumulative rain and resulted in complete drainage through the $6 \mathrm{~cm}$ thick soil; but in Run 2, drainage water was collected after the addition of only $10 \mathrm{~mm}$ of rain. This can be attributed to different boundary conditions, where soil water content differed from Run 1. However, drainage attained a steady rate indicating refill from the top. In addition, the initiation of drainage in Run 2 occurred at $16 \mathrm{~mm}$ of rain, which is not too dissimilar to Run 1 (Fig. 6a).
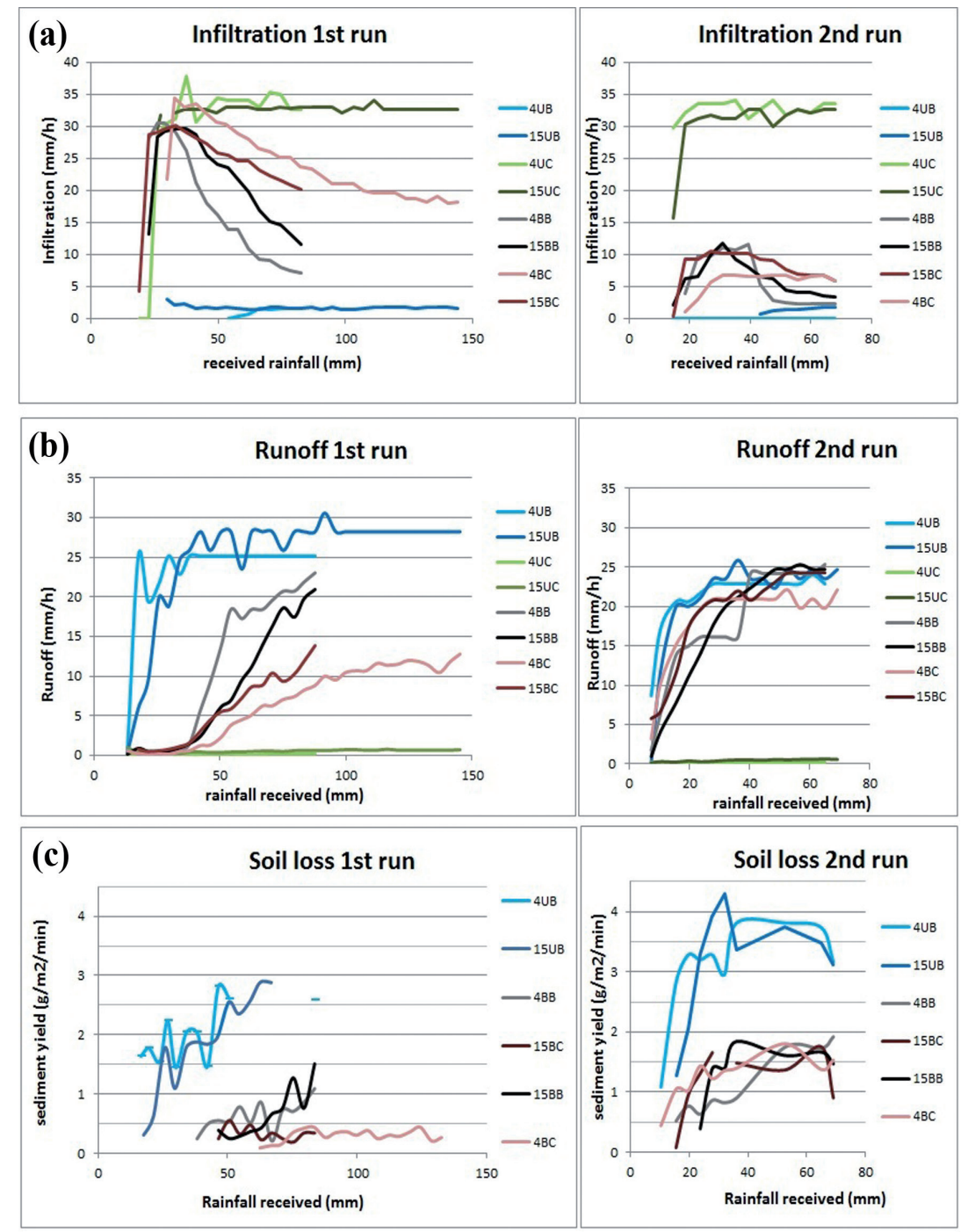

Figure 6. Rainfall simulator outputs for (a) infiltration, (b) runoff and (c) soil loss for the two runs, for various treatments and aggregate size classes $(4 \mathrm{~mm}$ and $15 \mathrm{~mm})$. Note: UB=unburnt bare soil; $U C=$ soil with leaf litter; $B B=$ burnt soil with ash removed; $B C=$ burnt soil with ash on surface; R1: First rainfall simulation run, R2: second rainfall simulation run. 


\subsubsection{Unburnt Bare and Unburnt Cover (reference) treatments}

Overall, the drainage results were as expected with cover plots revealing higher steady infiltration rates than the unburnt bare soil samples (Fig. 6a). In the first simulation, the unburnt bare soil treatments (4UB and 15UB) had a very low final steady infiltration rate of $1.5 \mathrm{~mm} \mathrm{~h}^{-1}$ whilst the unburnt cover treatments (4UC and 15UC) had a much higher infiltration rate of $33 \mathrm{~mm} \mathrm{~h}^{-1}$. In the second simulation, the same trend was readily evident (Fig. 6a-R2). Both cover treatments drained at a rate of $33 \mathrm{~mm} \mathrm{~h}^{-1}$, showing that all of the simulator's rain, delivered at a rate of $33 \mathrm{~mm} \mathrm{~h}^{-1}$, was being infiltrated; while the bare treatments achieved a maximum rate of $1.6 \mathrm{~mm} \mathrm{~h}^{-1}$ (Fig. 6a-R2).

\subsubsection{Burnt Treatments}

The drainage plots (Fig. 6a) for the various treatments, especially when comparing Runs 1 and 2, revealed a mixed response. The drainage story for cover (4UC and 15UC) and bare (4UB and 15UB) treatments provided a consistent response between Runs 1 and 2, although not all of the other treatments respond quite as well. For instance, in Run 1, samples with ash (4BC and 15BC) had a higher infiltration rate than the samples without ash (4BB and $15 \mathrm{BB})$, even though they did not attain a steady infiltration rate for a considerable period of time. Treatment $4 \mathrm{BC}$ achieved a steady infiltration rate of $18 \mathrm{~mm} \mathrm{~h}^{-1}$, but this occurred after the application of $120 \mathrm{~mm}$ of rain, delivered at $33 \mathrm{~mm} \mathrm{~h}^{-1}$. In comparison, the bare (4UB and 15UB) and cover (4UC and 15UC) samples reached and maintained a steady infiltration rate of 1.5-1.6 $\mathrm{mm} \mathrm{h}^{-1}$ after only $25 \mathrm{~mm}$ of rain supplied at the same rate of $33 \mathrm{~mm} \mathrm{~h}^{-1}$ (Fig. 6a).

In comparison, the drainage response of the burnt treatments in Run 2 was very subdued (Fig. 6a-R2), compared to Run 1 (Fig. 6a-R1). All burnt treatments in Run 2 achieved steady infiltration rates of between 2-7 $\mathrm{mm} \mathrm{h}^{-1}$ after $48 \mathrm{~mm}$ of rain. This contrasts with the almost unchanged infiltration rates in Runs 1 and 2 between the cover and bare treatments, that reached their stable infiltration rates after only $16 \mathrm{~mm}$ of rain (Fig. 6a-R2).

\subsection{Runoff and sediment generation}

Runoff was readily generated from all treatments except for the unburnt cover treatments. During Run 1, runoff was initiated after 13-16 mm of accumulated rain (Fig. 6b-R1). However, beyond this, there was very little commonality evident in terms of the measured runoff, between the rainfall simulations and the treatments.

\subsubsection{Unburnt Bare and Unburnt Cover (reference) treatments}

As expected, the reverse situation to the drainage plots (Fig. 6a) was evident in Run 1 as the bare reference treatments (4UB and 15UB) had the highest runoff response at between 25-28 $\mathrm{mm} \mathrm{h}^{-1}$ after $14 \mathrm{~mm}$ of rain, whilst the cover reference treatments (4UC and 15UC) resulted in very low runoff rates of $0.2-0.8 \mathrm{~mm} \mathrm{~h}^{-1}$, also after $14 \mathrm{~mm}$ of rain (Fig. 6b-R1). The big difference between the unburnt bare and unburnt cover treatments was that the onset of runoff responded 2-3 times faster than drainage during Run 1 (Fig. 6a, b).

In Run 2, the response to runoff was even faster at $7 \mathrm{~mm}$ of rain for both the bare (4UB and 15UB) and the cover samples (4UC and 15UC) and some 7-8 times faster than the 
comparable drainage runs (Fig. 6a, b). Runoff rates in Run 2 for the bare samples were 23 $\mathrm{mm} \mathrm{h}^{-1}$ which are comparable to Run 1 . This is also the case for the cover samples with runoff rates of 0.2-0.6 $\mathrm{mm} \mathrm{h}^{-1}$ (Fig. 6b-R2).

In relation to sediment yield, due to the very low runoff rates, no sediment was produced from the unburnt cover treatments (4UC and 15UC) in both Runs 1 and 2 (Fig. $6 \mathrm{~b}, \mathrm{c})$. However, for the unburnt bare samples, the story was very different. Sediment yields steadily climbed and peaked at $2.8 \mathrm{~g} \mathrm{~m}^{-2} \mathrm{~min}^{-1}$ (Fig. 6c-R1). In Run 2, the unburnt bare treatment (15UB) responded quickly to rainfall, reaching a peak of $4.2 \mathrm{~g} \mathrm{~m}^{-2} \mathrm{~min}^{-1}$ after $25 \mathrm{~mm}$ of rainfall before settling to $3.5 \mathrm{~g} \mathrm{~m}^{-2} \mathrm{~min}^{-1}$ between $30-70 \mathrm{~mm}$ of rain (Fig. 6c-R2). The finer bare treatment (4UB) similarly responded promptly to rainfall, reaching an average of about $3.7 \mathrm{~g} \mathrm{~m}^{-2} \mathrm{~min}^{-1}$, between $30-70 \mathrm{~mm}$ of rainfall (Fig. 6c-R2).

\subsubsection{Burnt Treatments}

Runoff from the burnt treatments without ash (4BB and $15 \mathrm{BB})$ generated more runoff than the burnt cover treatments with ash (4BC and 15BC), but not as much as the reference unburnt bare (4UB and 15UB) reference samples (Fig. 6b). The same but inverse trend was also evident for Run 1 drainage plots (Fig. 6a-R1). But unlike the unburnt cases, the burnt cover and burnt bare treatments did not reach an equilibrium runoff rate in Run 1 (Fig. 6b-R1).

In Run 2, apart from the unburnt covered (4UC and 15UC) treatments which registered almost no runoff, all other treatments appeared to eventually group together to reach a steady runoff rate of between $20-25 \mathrm{~g} \mathrm{~m}^{-2} \mathrm{~min}^{-1}$ after $40 \mathrm{~mm}$ of rain (Fig. 6b$\mathrm{R} 2)$. Furthermore, less rain $(7 \mathrm{~mm})$ was needed to produce runoff during Run 2 . The reference soil (4UC and 15UC) with needle cover is almost completely protected against rain splash and detachment. The hydrologic attributes of the burnt treatments (BB) is similar to the reference bare (UB) soil with rates reaching $20-25 \mathrm{~mm} \mathrm{~h}^{-1}$. Striking is the unsteadiness of sediment yield rates, with the burnt samples reaching maximum runoff rates after $35 \mathrm{~mm}$ compared to the reference bare sample that was achieved after $25 \mathrm{~mm}$ (observe the sudden rise of 4BB) (Fig. 6b-R2).

Sediment yields in Run 1 from the burnt bare (BB) and soil with ash cover (BC) treatments are approx. $30 \%$ of that generated from the unburnt (UB) soil treatment (Fig. 6c-R1). This is clearly evident in Run 2, where sediment yields from the reference unburnt (UB) samples vary between 3-4 $\mathrm{g} \mathrm{m}^{-2} \mathrm{~min}^{-1}$, between 20-70 $\mathrm{mm}$ of rain, with the burnt bare (BB) and burnt cover (BC) yielding $50 \%$ of the BB treatments at $1-2 \mathrm{~g} \mathrm{~m}^{-2}$ $\mathrm{min}^{-1}$, measured between 30-70 mm of rain during Run 2 (Fig. 6c-R2).

Soils that were subjected to the burning process (BB and BC) appear to have a lower erosion potential than for the unburnt bare (UB) treatments. Of course, the treatment with the lowest erosion potential is an unburnt covered (UC) soil, given their higher drainage, lower runoff and thus lower erosion potential.

\section{Discussion}

Moody et al. (2013), in their extensive review and assessment of the current issues evident in post-wildfire erosion processes, identify that the highest priority in future 
post-wildfire runoff and erosion research rests in achieving a better understanding of the "relations between soil properties and burn severity metrics (which includes soilwater repellency metrics)" (p. 30). Some of the identified soil properties include soil water content, soil hydraulic characteristics, physical changes of soils resulting from wildfires and the impacts upon the post-wildfire erodibility of soils (Moody et al., 2013). The research presented in this study contributes to the existing body of knowledge on hydraulic properties resulting from an analysis of soil physical properties by assessing the impact of wildfire on a Rendzina soils with differing aggregate sizes under a range of cover and burning treatments. This is then used to determine the impact in the laboratory of WR and ash on the hydrological and erosive attributes of a Mediterranean soil from which effective management approaches and decisions can be made. Thus, if we can readily understand the impact of these soil parameters, we can therefore predict how changes and the responses of soils to external influences occur.

This study set out to determine the relative importance of fire-induced soil WR on hydrological and erosional processes. The degree and spatial distribution of WR varies considerably with fire severity, soil and vegetation type, soil moisture content and the time elapsed since burning. Furthermore, an inverse relationship exists between soil moisture and WR (Doerr and Thomas, 2000; Bodí et al., 2013). This is further complicated by the presence of ash which may also play a role in affecting surficial flows and the erosion potential of a soil.

\subsection{Impact of ash on hydrology and erosion}

Over recent decades, there have been numerous studies investigating the spatial and temporal impact of ash deposits on runoff and erosion processes, erosion rates, and water quality (Woods and Balfour, 2010). The research literature has been inconclusive on the impacts of ash on hydrology and erosion with studies identifying that ash temporarily reduces infiltration, either by clogging soil pores or by forming a surface crust (Onda $e t$ al., 2008; Balfour and Woods, 2013). However, there is also compelling research stating that, at least for a few weeks after burning, ash increases infiltration compared to unburnt soils by storing moisture and protecting the underlying soil from sealing (Woods and Balfour, 2010; Gabet and Sternberg, 2008).

Furthermore, there is also disagreement in the literature about the impact of ash on soil infiltration and runoff potential. One body of research contends that an ash layer protects the soil surface against the energy of raindrops (Ebel et al., 2012; Bodí et al., 2013), which, without ash layer, the unprotected soil surface would be exposed to the energy of raindrops that would ultimately destroy the soil aggregates and allow the formation of a soil crust of fine particles impenetrable by water, thereby impeding the infiltration of water into the soil (Belnap, 2006). Yet another body of research has found that ash reduces infiltration by clogging soil pores (Balfour and Woods, 2013; Bodí et al., 2013) and increasing overland flow. In our study, the latter case, was not observed, which might be caused by the limited thickness of the ash layer in this study.

\subsubsection{Impact of ash on hydrology}

The first detectable effect of ash in this study was the significant delay in overland flow and sediment generation largely attributable to the buffering effect of the ash layer 
(Fig. 6b). The ash layer can also absorb moisture, creating a buffer in the water balance on the hillslope. This effect of ash on the hydrologic response is visible as one looks at the hydrographs: higher rates of infiltration at the onset of the simulation (buffer effect) (Fig. 6a), creating a lag-time in the runoff formation (Fig. 6b). This effect was also observed by Cerdà and Doerr (2008) and Larsen et al. (2009) who confirm the ability of ash to store a considerable quantity of water through its porous characteristics, as much as the thickness of the ash layer itself. Moreover, Etiégni et al. (1991) studied wood ash structure and its change during wetting, and suggested that ash (which is essentially hydrophilic) particles tend to swell through absorption of water into the pores by capillary action. Bodí et al. (2011) indicated that ash typically delays the onset of runoff proportionally to its thickness, due to its high water storage capacity. Once ash is saturated, runoff and subsurface flow between the ash and soil starts until both layers reach an equilibrium, after which the soil infiltration rate dominates the process. As soon as the ash has been removed by overland flow, wind or management treatments, the buffering effects of the ash layer are negated and higher runoff and erosion rates are the result.

The second observation that can be made in this experiment is that the response to rainfall in the second rainfall simulation was the same for both burnt treatments: where ash was removed after the fire and where it was left on the surface (Fig. 6). Because ash was only removed after the fire, the soil underneath the ash was the same in both burnt treatments. We observed that the response of the two treatments was the same after ash was eventually washed off. This implies that ash in this experiment only had a temporary effect in protecting and delaying soil erosion and runoff, and did not influence the soil response to rainfall after the first simulated rainfall event, which removed the ash. The likely reason for this is that the ash did not infiltrate into the pores of the soil, and thus clogging and reduced infiltration were not evident through this research.

There are a number of possible explanations for the absence of ash infiltration into the soil. Bodí et al. (2013) stated that ash is a highly variable substance, which depends upon a range of factors including the origin of the ash, characteristics of the organic matter/vegetation which was combusted (stem, bark, leaf), plant species and the moisture content of the vegetation at the time of the fire. Furthermore, fire intensity and fire temperature can also be of relevance. Residual organic $\mathrm{C}$ is a darkening pigment in ash, and thus the ash colour can indicate the relative degree of combustion. For instance, complete combustion of pine wood and oak wood at $>500^{\circ} \mathrm{C}$ produces a light coloured ash (greyish-white) composed of alkaline oxides ( $\mathrm{Ca}, \mathrm{K}$ and $\mathrm{Mg}$ oxides) which reacts with atmospheric $\mathrm{CO}_{2}$ and water vapour to form soluble hydroxides and carbonates (Goforth et al., 2005). Black ash, by comparison, contains a higher proportion of charred organic material than light-coloured ash.

Balfour (2007) argued that fire-induced ash may contribute to infiltration reduction in two ways: 1) by white ash filling pore spaces, and 2) by black ash becoming oriented parallel to the soil surface creating a thin layer of low porosity and permeability within the upper few millimeters of the soil. Our experiment involved a relatively low temperature fire, which led to partial combustion and the production of back ash. The relatively large size of the ash particles may have influenced ash infiltration, which concurs with other 
studies (Bodí et al., 2011, 2012), where once ash is saturated, the flow tends to adjust to an infiltration rate similar to the soil itself.

A third important feature of the ash layer is the protection provided on the soil surface against the energy of raindrops in terms of both sediment entrainment and crustformation which has been widely reported in the literature in both field and laboratory settings (Kinner and Moody, 2005; Cerdà and Doerr, 2008; Larsen et al., 2009; Woods and Balfour, 2008; Zavala et al., 2009). In this study, the protection provided by ash is reflected in the delay in sediment yield from the burnt soils with ash compared to the burnt soil where the ash was removed (Fig. 6c).

\subsubsection{Impact of ash on erosion rates}

No soil loss was detected from treatments with complete needle cover, while sediment yields for the bare treatments reached $6 \mathrm{~g} \mathrm{~m}^{-2} \mathrm{~min}^{-1}$ of rain. The burnt samples reached soil loss values between 0.5 and $2.5 \mathrm{~g} \mathrm{~m}^{-2} \mathrm{~min}^{-1}$ (without ash and with ash, respectively (Fig. 6c)). After the first run, the ash appears to have been washed away, as there was no discernable difference between the samples where ash was present and where it was removed (Fig. 6c-R1). In the second run, the erosion and soil loss rates of burnt soil surfaces with and without ash, were comparable (Fig. 6c-R2), as diminishing ash protection and soil crust development thereby increased the runoff and erodibility potential. This suggests that the ash only provided some temporary, initial protection against the impacts of rain drops on the soil surface, with little impact upon infiltration in the soil profile as suggested by some researchers (c.f. Stoof et al., 2010).

However, there are major differences evident in erosion rates between the non-burnt and burnt treatments (Fig. 6c). This difference cannot be explained by the presence of ash alone as it was present in the burnt samples where the ash was blown off as much as in the samples where the ash remained on the surface. The presence of an ash layer on a burnt site is often short-lived with ash being removed off-site by rainfall or wind, with its soluble components being dissolved during rainfall, or incorporated into the soil by physical and bioturbation processes. However, the presence of ash on the soil surface in the initial period after a fire can be very important (Bodí et al., 2011).

\subsection{Aggregate size}

This study found that aggregate size does not appear to have an influence on the way the soil reacts to fire and to the subsequent impacts of rainfall. Mataix-Solera et al. (2011) undertook a detailed reviewed of the diverse reaction of aggregates to fire and noted that the response of aggregates to fire depends on the composition of the aggregates. Characteristics including organic matter content, microbial biomass, water repellency and texture, all play an important role in governing the aggregate size distribution (Mataix-Solera et al., 2011). Furthermore, they stated that low severity fires do not produce notable changes in the stability of the aggregates, while high severity fires can induce important changes in their properties, but with different effects depending on the soil type. In our study, for two aggregate sizes at 4 and $15 \mathrm{~mm}$, soil type and fire 
severity were kept the same in all treatments. The results revealed no notable impacts of aggregate size on either runoff or erosion (Fig. 6).

\subsection{Role of Water Repellency}

WR is a point-measured feature of soils and varies according to wide array of variables including fire temperature, soil particle size fraction (Doerr and Shakesby, 2009; Mataix-Solera et al., 2013), organic matter content, organic matter/clay ratios and clay mineralogy (Mataix-Solera et al., 2008), soil moisture and pre-fire vegetation type (Arcenegui et al., 2007).

In this experiment we aimed at isolating the effects of fire on the formation and persistence of soil WR throughout two successive rainfall simulations. Between the two rainfall simulations, a drying period, that simulated a cycle of wetting and drying, allowed for more natural soil hydrology and the potential (re-)establishment of hydrophobicity. WR was formed from a simulated fire which had high enough temperatures $\left(175-280^{\circ} \mathrm{C}\right)$ to change or intensify the degree of WR at the soil surface. By measuring WR before, between and after each rainfall simulation, the degree and spatial variation of WR could be evaluated to determine the preferential surface flow. Several days after the fire, the burnt surfaces showed signs of hydrophobicity. Despite WR being relatively low (level 2-3: Table 2), there was a clear difference between the burnt and unburnt samples, with the unburnt soil surfaces being completely hydrophilic (Table 3).

Different mechanisms are playing a role in how the burnt soil will react to the simulated rainfall including sink dynamics, soil crusting and WR, and consequently, it is difficult to distinguish any dominant factors at any given moment. However, some specific features in the runoff hydrographs of the samples provides clues about the soil hydrological processes operating during the experiment (Fig. 6b). The difference in runoff in the burnt treatments in the first run could largely be a consequence of WR. Doerr et al. (2003) stated that soil WR causes infiltration rates to be much lower than the potential infiltration rate, therefore enhancing runoff, that after long dry periods, hydrophobicity enhances the Hortonian runoff response. This helps to explain the initially low infiltration rates and therefore high runoff for the non-burnt soil treatments (Fig. 6a, b).

Some interesting phenomenon during the first rainfall simulation were observed in the runoff hydrographs, especially where ash was removed after fire. These treatments show a pattern that after some initial rainfall, there is a rapid increase in the runoff rate which suddenly declines and establishes a constant runoff rate (Fig. 6b). These drops of $>1 \mathrm{~mm} \mathrm{~h}^{-1}$ in runoff might be caused by reading errors, but in two of these three cases, a sudden and temporary 'freeze' in drainage level occurs at the same time (Fig. 6b R2 after 15 and $30 \mathrm{~mm}$ of received rainfall depth). Although the timing of this 'freeze' is not evident in all of the treatments, the reason for it may be the same. A possible explanation for this may be the breakdown of a subsurface WR layer causing a momentary freeze in drainage decline, which causes a temporary increase in drainage with no further increase in runoff. Another factor at play might be the breakdown of surface WR, whereby sinks 
in the vicinity of these hydrophobic areas lose their function and runoff water has more available area to infiltrate.

\subsubsection{Preferential flow resulting from $W R$}

When investigating the effect of WR, it became evident that not only the degree of WR, but also the spatial variability influences the soil's hydrological functioning. Although WR differences, when averaged over the whole surface, were not distinctively different for the different treatments, there was however a large difference in the pattern of hydrophobic and hydrophilic patches. The most extensive WR patches were found on burnt soils where ash had not been removed. WR is largest on both treatments (with and without ash) after the first rainfall simulation and both are largely hydrophilic after the second rain event. However, even though large areas were hydrophilic after this second rainfall simulation, the WR of soil particles appears to have moved downslope and accumulated at the base of the plots or in the main drainage thalweg, being specifically evident in the burnt soils without the protection of the ash layer (Fig. 5). When looking at the larger implications of WR not being broken down but transported downslope, may ensure that the effects of fire-induced WR, remains in the system for longer periods than was evident from the averaged WR measurements. For the plot size experiment, these implications are relatively minor; but at the catchment scale, these processes can have a major impact as noted by Shakesby (2011) and Cawson et al. (2013). They highlighted that while the effects of WR on runoff and erosion have been clearly demonstrated at the spot-to-plot scale, its importance is difficult to demonstrate at a catchment scale.

Infiltration is the key process for the generation of hillslope runoff and soil WR, which highly influences the infiltration potential of the soil. It is essential to understand these processes on larger scale to assess the potential runoff and the likeliness of the runoff the reach the outlet of a catchment. The delivery pathway is dependent on catchment positioning and management practices. The management and man-made structures, can influence the connection between the runoff sources and sinks (Bracken and Croke, 2007; Keesstra et al., 2009a,b; Baartman et al., 2013; López-Vicente et al., 2013).

\subsubsection{Impact of WR on erosion rates}

Previous studies have indicated that while most of the blanketing ash is removed by wind and running water, its soluble components are dissolved during rainfall or incorporated into the soil by physical and bioturbation processes (Bodí et al., 2011). Ash leachates have been reported to reduce soil erodibility by facilitating flocculation of the dispersed clays (Giovannini and Lucchesi, 1997; Holcomb and Durgin, 1979). Soil loss from the burnt soil treatments were much lower than the unburnt treatments despite similar quantities of runoff. However ash alone cannot be the reason for this difference, given that there needs to be a variance in the soil characteristics to explain this. The first possibility is the WR generated by the fire within the experiment, as the unburnt samples were completely hydrophilic. WR was measured during the experiment and showed a different pattern after fire and after the rainfall simulations. The hydrophobic patches still present in some scattered locations of the plot after rainfall simulation, might be 
protecting the soil in places where water accumulates (lowering the soil erosion rates), while the amount of water that is generated as runoff is similar as for a completely hydrophilic unburnt treatment. Secondly, aggregate stability could also have changed due to the heat of the fire. While Mataix-Solera et al. (2011) state that aggregate stability can be both positively as well as negatively affected by fire, in our case, aggregates may have been more stable after the fire event. The third possible explanation for the reduced erosion on the burnt plots can be due to the flocculation of the clay fraction by electrolytes from the ash leachate. Fluids that disperse the soil are more erosive than those causing flocculation. Electrolytes and cations in particular allow the negatively charged clays to form flocs, making the clay less detachable and more resistant to erosion (Holcolmb and Durgin, 1979).

\subsection{Insights for post-fire management decisions}

The insights generated in this study may help contribute to improvements in the design of best management practices for Mediterranean contexts after a fire event. Careful management approaches need to be considered by factoring in the increased risk of post-fire soil erosion due to WR and ash removal in the immediate post-fire period when the ecosystem is most vulnerable. As evident in other studies, hydrophobicity of the surface and subsurface layers fades not within a short timeframe (Dekker et al., 2005; Diamantopoulos et al., 2013). Slight to moderate levels of WR at the surface are not removed by $>140 \mathrm{~mm}$ of simulated rain. Other studies in field settings have shown that severe levels at the subsurface were not removed even after a rainfall depth $>600 \mathrm{~mm}$ (Wittenberg, 2012). If WP is present within a whole layer, at a high enough level and where all the protective cover is burnt, then this may pose serious risks of slope wash and soil degradation.

Adams (2013) refers to tipping points in forest ecosystems that have become more vulnerable recently due to the threats of climate change and changes in forest use and forestry management. Therefore, site and climate-specific management is needed to mitigate the risks associated with ecosystem deterioration. In numerous countries, there have been many management strategies tested in relation to management effectiveness. In Pine and Eucalypt forests in Greece and Australia, where salvage logging occurred, it was shown to be ineffective in enhancing re-vegetation rates, especially for herbaceous vegetation (Spanos et al., 2010), and furthermore, the log drag lines served as an extension of the drainage network enhancing runoff and sediment yield by orders of magnitude (Smith et al., 2011). This also had a negative effect on water and sediment delivery from the catchment (Spanos et al., 2005). McIver and Starr (2001) stressed that logging disturbs the surface after fire, but the way logging is done influences the size of the impact of logging on the change in sediment and water generation on slopes. They argue that the use of site specific management approaches were needed to limit the effect of logging. Also, Marañón-Jiménez et al. (2013) found that salvage logging was identified to have a negative effect on eco-physiological performance and growth of naturally-regenerating pine seedlings, compared to the alternative post-fire management practices in which burnt logs and branches are left in situ. 
In many fire-affected areas, the increases in runoff and erosion rates are mitigated by the use of mulch treatments. Robichaut et al. (2013) stated that wood strand mulch reduced sediment yields for the first four post-fire years, but wheat straw-mulch and hydro-mulch did not significantly reduce sediment yields in any post-fire year. In addition, they stress that fire-specific results provide the more accurate representation of potential post-fire mulch treatment effectiveness. Prats et al. (2012) also found that mulching is very effective in some specific cases, especially when the severity of the fire was very high. Furthermore, these researchers also stressed that post-fire management, needs to be tailored specifically to the specific needs of the site in terms of soil type/s, climate and pre-fire management, and to the severity of the fire.

Direct post-fire management actions like logging and salvage create disturbances to the surface, especially to the protecting ash layer, which would otherwise protect the surface from erosion for at least the first rainfall event. This was also shown in the research experiment presented in this study. Two aspects in relation to possible management implications can be stated from our work. Firstly, ash has several important roles in the immediate period post- forest fire. It protects the soil from rain splash erosion in a similar way as non-burnt ground cover would protect the soil; and it was a high water holding capacity, absorbing the rainfall, and thereby reducing runoff. Secondly, the management implications of this work is the fact that as soon as ash is removed from the soil by rainfall, the surface reacts the same way as a soil without ash, suggesting that there is little influence of ash infiltration on the hydrological functioning of the soil. This highlights the important benefits for keeping ash in place for as long as possible. Management actions including mulching would further enhance the stability of the soil surface from the effects of soil erosion.

\section{Conclusions}

The research presented in this study contributes to the existing body of knowledge on hydraulic properties resulting from an analysis of soil physical properties. By assessing the impact of wildfire on a Rendzina soils with differing aggregate sizes under a range of cover and burning treatments it is possible to determine the impact in the laboratory of WR and ash on the hydrological and erosive attributes of a Mediterranean soil from which effective management approaches and decisions can be made. For the two aggregate sizes of 4 and $15 \mathrm{~mm}$, the results revealed no notable impacts attributable to aggregate size on either runoff or soil erosion processes.

The impact of WR on hydrological and erosional processes is further complicated by the presence of ash which may also play an important role in altering the nature of surficial flows and thus the erosion potential of a soil. To better understand the role of WR in influencing runoff and infiltration rates, a series of rainfall simulations under laboratory conditions were undertaken. These laboratory simulations were carried out on undisturbed burnt soil samples (BC), burnt samples where the ash was removed (BB) and control soil samples with (UC) and without (UB) a covering litter layer. The manually-simulated fire combusted all litter cover and induced water repellency on all surfaces. Strong WRlevels were recorded $24 \mathrm{~h}$ after burning on parts of the surface of the BB sample; while 
other samples showed slight-moderate WR levels. Two rainfall simulations $(140 \mathrm{~mm}$ cumulative rain) decreased WR in most cases, although it was still present on the surface.

In relation to the impact of ash on hydrological and erosional processes in this study, there were three detectable outcomes which included: 1) the significant delay in overland flow and sediment generation largely attributable to the buffering effect of the ash layer; 2) ash only had a temporary impact in protecting the soil surface and thus in delaying soil erosion; and 3) the protection provided by ash in minimizing the impacts of rain splash on the surface of the soil delaying the sediment yield from the burnt treatments with little detrimental impact of the ash upon the infiltration rates of the soil profile.

Despite WR being relatively low, there was a clear difference between the burnt and unburnt samples, with the unburnt soil surfaces being completely hydrophilic. Differences in runoff between the burnt treatments especially in the first experimental run, could largely be attributable to WR. Given soil WR causes infiltration rates to generally be lower than the potential infiltration rate, whilst commensurately enhancing runoff (Doerr et al., 2003), it is suggested here that after prolonged dry phases, hydrophobicity enhances the response of Hortonian runoff. This, for the non-burnt treatments, helps to explain the initially low infiltration rates and therefore high runoff rates.

Even with similar runoff, soil loss from burnt soil treatments were considerably lower than for the unburnt treatments. Ash alone was not seen as the cause for this variation but there are several other possibilities, including: 1) the WR generated through the effects of burning in this experiment; 2) alteration in aggregate stability through the fire process, and; 3) clay flocculation from ash leachates.

Possible management implications based upon this research are that: 1) ash can have several important roles immediately after a forest fire by protecting the forest soil from rain splash erosion, and with its high water holding capacity, absorbs rainfall, thereby reducing runoff, and; 2) ash has no negative influence upon soil infiltration demonstrating the important benefits of ensuring the longer term maintenance of post-fire ash within the burnt landscape. Finally, management actions including mulching further enhance soil stability and minimize soil erosion.

\section{References}

Adams, M.A. 2013. Mega-fires, tipping points and ecosystem services: Managing forests and woodlands in an uncertain future. Forest Ecology and Management 294, 250-261.

Arcenegui, V., Mataix-Solera, J., Guerrero, C., Zornoza, R., Mayoral, A.M., Morales, J. 2007. Factors controlling the water repellency induced by fire in calcareous Mediterranean forest soils. European Journal of Soil Science 58, 1254-1259.

Baartman, J.E.M., Masselink, R.H., Keesstra, S.D., Temme, A.J.A.M. 2013. Linking landscape morphological complexity and sediment connectivity. Earth Surface Processes and Landforms 38, 1457-1471.

Balfour, V., Woods, S.W. 2007. Does wildfire ash block soil pores? A micromorphological analysis of burned soils. AGU Fall Meeting Abstracts, F1695.

Balfour, V.N., Woods, S.W. 2013. The hydrological properties and the effects of hydration on vegetative ash from the Northern Rockies, USA. Catena 111, 9-24. 
Belnap, J. 2006. The potential roles of biological soil crusts in dryland hydrologic cycles. Hydrological Processes 20, 3159-3178.

Blake, W.H., Wallbrink, P.J., Wilkinson, S.N., Humphreys, G.S., Doerr, S.H., Shakesby, R.A., Tomkins, K.M. 2009. Deriving hillslope sediment budgets in wildfire-affected forests using fallout radionuclide tracers. Geomorphology 104, 105-116.

Bodí, M.B., Mataix-Solera, J., Doerr, S.H., Cerdà, A. 2011. The wettability of ash from burned vegetation and its relationship to Mediterranean plant species type, burn severity and total organic carbon content. Geoderma 160, 599-607.

Bodí, M.B., Doerr, S.H., Cerdà, A., Mataix-Solera, J. 2012. Hydrological effects of a layer of vegetation ash on underlying wettable and water repellent soil. Geoderma 191, 14-23.

Bodí, M.B., Muñoz-Santa, I., Armero, C., Doerr, S.H., Mataix-Solera, J., Cerdà, A. 2013. Spatial and temporal variations of water repellency and probability of its occurrence in calcareous Mediterranean rangeland soils affected by fires. Catena 108, 14-25.

Bracken, L.J., Croke, J. 2007. The concept of hydrological connectivity and its contribution to understanding runoff-dominated geomorphic systems. Hydrological Processes 21, 17491763.

Cawson, J.G., Sheridan, G.J., Smith, H.G., Lane, P.N.J. 2013. Effects of fire severity and burn patchiness on hillslope-scale surface runoff, erosion and hydrologic connectivity in a prescribed burn. Forest Ecology and Management 310, 219-233

Cerdà, A., Doerr, S.H. 2008. The effect of ash and needle cover on surface runoff and erosion in the immediate post-fire period. Catena 74, 256-263.

Certini, G., 2005. Effects of Fire on Properties of Forest Soils: A Review. Oecologia 143, 1-10.

DeBano, L.F., 2000. The role of fire and soil heating on water repellency in wildland environments: a review. Journal of Hydrology 231-232, 195-206.

Dekker, L.W., Oostindie, K., Ritsema, C.J. 2005. Exponential increase of publications related to soil water repellency. Australian Journal of Soil Research 43, 403-441.

Diamantopoulos, E., Durner, W., Reszkowska, A., Bachmann, J. 2013. Effect of soil water repellency on soil hydraulic properties estimated under dynamic conditions. Journal of Hydrology 486, 175-186.

Doerr S.H., Thomas, A.D. 2000. The role of soil moisture in controlling water repellency: new evidence from forest soils in Portugal. Journal of Hydrology 231-232, 134-147.

Doerr, S.H., Shakesby, R.A. and Walsh, R.P.D., 2000. Soil water repellency: its causes, characteristics and hydro-geomorphological significance. Earth-Science Reviews 51, 33-65.

Doerr, S.H., Ferreira, A.J.D., Walsh, R.P.D., Shakesby, R.A., Leighton-Boyce, G., Coelho, C.O.A. 2003. Soil water repellency as a potential parameter in rainfall-runoff modelling: Experimental evidence at point to catchment scales from Portugal. Hydrological Processes 17, 363-377.

Doerr, S.H., Shakesby, R.A. 2009. Soil Water Repellency: A Key Factor in Post-Fire Erosion. In Fire Effects on Soils and Restoration Strategies, A. Cerdà, P. Robichaud (eds.), Science Publishers Inc., Enfield, New Hampshire, pp. 197-224.

Ebel, B.A., Moody, J.A., Martin, D.A. 2012. Hydrologic conditions controlling runoff generation immediately after wildfire. Water Resources Research 48, art. no. W03529.

Etiégni, L., Campbell, A., Mahler, R. 1991. Evaluation of wood ash disposal on agricultural land. 1. Potential as a soil additive and liming agent. Commun. in soil sci. plant anal. 22, 243-256.

Fernández, C., Vega, J.A., Fonturbel, T., Pérez-Gorostiaga, P., Jiménez, E., Madrigal, J. 2007. Effects of wildfire, salvage logging and slash treatments on soil degradation. Land Degradation and Development 18, 591-607. 
Gabet, E.J., Sternberg, P. 2008. The effects of vegetative ash on infiltration capacity, sediment transport, and the generation of progressively bulked debris flows. Geomorphology 101, 666-673.

Giovannini, G., Lucchesi, S. 1997. Modifications induced in soil physico-chemical parameters by experimental fires at different intensities. Soil Science 162, 479-486.

Goforth B.R., Graham R.C., Hubbert K.R., Zanner C.W., Minnich R.A. 2005. Spatial distribution and properties of ash and thermally altered soils after high-severity forest fire, southern California. International Journal of Wildland Fire 14, 343-354.

Holcomb, G.J., Durgin, P.B. 1979. Ash leachate can reduce surface erosion. Research Note PSW342. Pacific Southwest Forest and Range Experiment Station (Berkeley, Calif.), United States, Forest Service.

Inbar, M., Wittenberg, L., Tamir, M. 1997. Soil erosion and forestry management after wildfire in a mediterranean woodland, Mt. Carmel, Israel. International Journal of Wildland Fire 7, 285-294.

Inbar, M., Tamir, M., Wittenberg, L. 1988. Runoff and erosion processes after a forest fire in Mount Carmel, a Mediterranean area. Geomorphology 24, 17-33.

Keeley, J.E. 2009. Fire intensity, fire severity and burn severity: a brief review and suggested usage. International Journal of Wildland Fire 18, 116-126.

Keesstra, S.D., van Dam, O., Verstraeten, G., van Huissteden, J. 2009a. Changing sediment generation due to natural reforestation in the Dragonja catchment, SW Slovenia. Catena 78, 60-71.

Keesstra, S.D., Bruijnzeel, L.A., van Huissteden, J. 2009b. Constructing a sediment budget in a meso-scale catchment using a variety of methods: the Dragonja catchment, SW Slovenia. Earth Surface Processes and Landforms 32, 49-65.

Kinner, D.A., Moody, J.A. 2005. Drainage networks after wildfire. International Journal of Sediment Research 20, 194-201.

Larsen, I.J., MacDonald, L.H., Brown, E., Rough, D., Welsh, M.J., Pietraszek, J.H., Libohova, Z., De Dios Benavides-Solorio, J., Schaffrath, K. 2009. Causes of Post-Fire Runoff and Erosion: Water Repellency, Cover, or Soil Sealing? Soil Science Society of America Journal 73 (4), 1393-1407.

López-Vicente, M., Poesen, J., Navas, A., Gaspar, L. 2013. Predicting runoff and sediment connectivity and soil erosion by water for different land use scenarios in the Spanish PrePyrenees. Catena 102, 62-73.

Malkinson, D., Wittenberg, L. 2011. Post fire induced soil water repellency-Modeling short and long-term processes. Geomorphology 125, 186-192.

Mataix-Solera, J., Doerr, S.H. 2004. Hydrophobicity and aggregate stability in calcareous topsoils from fire-affected pine forests in southeastern Spain. Geoderma 118, 77-88.

Mataix-Solera, J., Arcenegui, V., Guerrero, C., Jordán, M.M., Dlapa, P., Tessler, N., Wittenberg, L. 2008. Can terra rossa become water repellent by burning? A laboratory approach. Geoderma 147(3-4), 178-184.

Mataix-Solera, J., Cerdà, A., Arcenegui, V., Jordán, A., Zavala, M.L. 2011. Fire effects on soil aggregation: A review. Earth-Science Reviews 109, 44-60.

Mataix-Solera, J., Arcenegui, V., Tessler, N., Zornoza, R., Wittenberg, L., Martínez, C., Caselles, P., Pérez-Bejarano, P., Malkinson, D., Jordán, M.M. 2013. Soil properties as key factors controlling water repellency in fire-affected areas: Evidences from burned sites in Spain and Israel. Catena 108, 6-13.

Marañón-Jiménez, S., Castro, J., Ignacio Querejeta, J., Fernández-Ondoño E., Allen, C.D. 2013. Post-fire wood management alters water stress, growth, and performance of pine regeneration in a Mediterranean ecosystem. Forest Ecology and Management 308, 231-239. 
McIver, J.D., Starr, L. 2001. A literature review on the environmental effects of postfire logging. Western Journal of Applied Forestry 16, 159-168.

Moody, J.A., Shakesby, R.A., Robichaud, P.R., Cannon, S.H., Martin, D.A. 2013. Current research issues related to post-wildfire runoff and erosion processes. Earth-Science Reviews 122, 10-37.

Onda, Y., Dietrich, W.E., Booker, F. 2008. Evolution of overland flow after a severe forest fire, Point Reyes, California. Catena 72, 13-20.

Pausas, J.G., Vallejo, V.R. 1999. The role of fire in European Mediterranean Ecosystems. In Remote sensing of large wildfires in the European Mediterranean basin, E. Chuvieco (ed.), Springer-Verlag, pp. 3-16.

Prats, S.A., MacDonald, L.H., Monteiro, M., Ferreira, A.J.D., Coelho, C.O.A., Keizer, J.J. 2012. Effectiveness of forest residue mulching in reducing post-fire runoff and erosion in a pine and a eucalypt plantation in north-central Portugal. Geoderma 191, 115-124.

Robichaud, P.R., Hungerford, R.D. 2000. Water repellency by laboratory burning of four northern Rocky Mountain forest soils. Journal of Hydrology 231-232, 207-219.

Robichaud, P.R., Lewis, S.A., Wagenbrenner, J.W., Ashmun, L.E., Brown, R.E. 2013. Post-fire mulching for runoff and erosion mitigation. Part I: Effectiveness at reducing hillslope erosion rates. Catena $105,75-92$.

Shakesby, R.A. 2011. Post-wildfire soil erosion in the Mediterranean: Review and future research directions. Earth-Science Reviews 105(3-4), 71-100.

Shakesby, R.A., Doerr, S.H., Walsh, R.P.D. 2000. The erosional impact of soil hydrophobicity: Current problems and future research directions. Journal of Hydrology 231-232, 178-191.

Smith, H.G., Sheridan, G.J., Lane, P.N.J., Bren, L.J. 2011. Wildfire and salvage harvesting effects on runoff generation and sediment exports from radiata pine and eucalypt forest catchments, south-eastern Australia. Forest Ecology and Management 261, 570-581.

Soil Survey Staff, 1975. Basic System of Soil Classification for Making and Interpreting Soil Surveys. Agric. Handb. No. 436. Soil Conservation Service, U.S. Department of Agriculture, 754 pp.

Spanos, I., Raftoyannis, Y., Goudelis, G., Xanthopoulou, E., Samara, T., Tsiontsis, A. 2005. Effects of postfire logging on soil and vegetation recovery in a Pinus halepensis Mill. Forest of Greece. Plant and Soil 278, 171-179.

Spanos, I., Raftoyannis, Y., Platis, P., Xanthopoulou, E. 2010. Post-fire management and recovery of a pine forest in Greece. Web Ecology 10, 27-31.

Stoof, C.R., Wesseling, J.G., Ritsema, C.J. 2010. Effects of fire and ash on soil water retention. Geoderma 159 (3-4), 276-285.

Tessler, N., Wittenberg, L., Greenbaum, N. 2013. Soil water repellency persistence after recurrent forest fires on Mount Carmel, Israel. International Journal of Wildland Fire 22, 515-526.

Thomas, A.D., Walsh, R.P.D., Shakesby, R.A. 2000. Post-fire forestry management and nutrient losses in eucalyptus and pine plantations, northern Portugal. Land Degradation and Development 11, 257-271.

Úbeda, X., Pereira, P., Outeiro, L., Martin, D. 2009. Effects of fire temperature on the physical and chemical characteristics of the ash from two plots of cork oak (Quercus suber), Land Degradation and Development, 20(6), 589-608.

Wittenberg, L. 2012. Post-fire soil ecology: Properties and erosion dynamics. Israel Journal of Ecology and Evolution 58, 151-164.

Wittenberg, L., Malkinson, D. 2009. Spatio-temporal perspectives of forest fires regimes in a maturing Mediterranean mixed pine landscape. European Journal of Forest Research 128, pp. 297-304. 
Wittenberg, L., Malkinson, D., Voogt, A., Leska, D., Argaman, E., Keesstra, S.D. 2011. The relative importance of soil water repellency in determining runoff-infiltration processes in burned Mediterranean forest soils. 3rd International meeting on Fire Effects on Soil Properties, University of Minho, Portugal.

Woods, S.W., Balfour, W.N. 2010. The effects of soil texture and ash thickness on the post-fire hydrological response from ash-covered soils. Journal of Hydrology 393, 274-286.

Zavala, L.M., Jordán, A., Gil, J., Bellinfante, N., Pain, C. 2009. Intact ash and charred litter reduces susceptibility to rain splash erosion post-wildfire. Earth Surface Processes and Landforms 34, 1522-1532. 